\title{
Mechanical and chemical dehydration for pre-drying of black oat silage
}

\section{Métodos mecânico e químico de desidratação na confecção de silagem pré-secada de aveia preta}

\author{
Murilo Klosovski Carneiro $^{1 *}$; Mikael Neumann²; Julio Cezar Heker Junior³; \\ Egon Henrique Horst ${ }^{4}$; Guilherme Fernando Mattos Leão; \\ Sandra Galbeiro ${ }^{6}$; Milaine Poczynek ${ }^{7}$
}

\begin{abstract}
This study aimed to evaluate mechanical and chemical methods of forage dehydration in the production of black oat pre-dried silage (Avena strigosa Schreb) under different dehydration times. The experiment was conducted in a randomized block experimental design with five replications and arranged in a 2 x 6 factorial scheme. We assessed two methods of dehydration, mechanical and chemical, over six dewatering times, being made at $0,3,6,9,12$, and 15 days after cutting or application of glyphosate. Harvest took place at 88 days after emergence, at pre-flowering. We evaluated dry biomass production at harvest, dry matter losses during dehydration in the field, losses during ensiling, gauging effluent output, and pre-dried silage chemical composition. There was an interaction between dehydration method and harvest time for most of the production characteristics. Chemical dehydration showed an enhanced dry matter recovery at the field level, however, unsuitable for pre-dried silage. The longer the dehydration period, the lower the losses for both analyzed methods; nevertheless, the chemical method reached unsatisfactory DM contents to produce good quality silage.
\end{abstract}

Key words: Avena strigosa Schreb. Bromatology. Winter cereals. Conserved forage. Dry matter recovery.

\section{Resumo}

Objetivou-se avaliar a interferência dos métodos mecânico e químico de desidratação da forragem na confecção de silagem pré-secada de aveia-preta (Avena strigosa Schreb), sob diferentes tempos de desidratação. $\mathrm{O}$ experimento foi realizado em delineamento de blocos ao acaso, com 5 repetições, em esquema fatorial 2 × 6, sendo dois métodos de desidratação, mecânico e químico, sobre seis tempos de desidratação, sendo 0, 3, 6, 9, 12 e 15 dias após o corte ou aplicação do herbicida glifosato. A colheita se deu aos 88 dias após emergência, em estádio de pré-florescimento. Foram avaliadas produção de fitomassa seca no momento da colheita, perdas de fitomassa seca durante a desidratação à campo, perdas durante a ensilagem, com aferição da produção de efluentes, além da composição bromatológica da silagem pré-secada. Houve interação entre método de desidratação x época de colheita, para a maioria

${ }^{1}$ M.e em Produção Vegetal, Universidade Estadual do Centro-Oeste, UNICENTRO, Guarapuava, PR, Brasil. E-mail: murilokcarneiro@hotmail.com

2 Prof. Dr., UNICENTRO, Guarapuava, PR, Brasil. E-mail: neumann.mikael@hotmail.com

${ }_{3}$ Discente, Curso de Mestrado no Programa de Pós-Graduação em Ciências Veterinárias, UNICENTRO, Guarapauva, PR, Brasil. E-mail:jr_heker@hotmail.com

${ }^{4}$ Discente do Curso de Mestrado no Programa de Pós-Graduação em Produção Vegetal, UNICENTRO, Guarapuava, PR, Brasil. E-mail: egonhh@yahoo.com

5 Discente, Curso de Doutorado no Programa de Pós-Graduação em Zootecnia, Universidade Federal do Paraná, UFPR, Curitiba, PR, Brasil. E-mail: gfleao@hotmail.com

${ }^{6}$ Prof $^{\mathrm{a}} \mathrm{Dr}^{\mathrm{a}}$, Universidade Estadual de Londrina, UEL, Londrina, PR, Brasil. E-mail: sgalbeiro@gmail.com

7 Discente, Curso de Graduação em Medicina Veterinária, UNICENTRO, Guarapuava, PR, Brasil. E-mail: milainepoc@gmail.com

* Author for correspondence 
das características de produção. O método de desidratação químico apresentou maior recuperação de fitomassa seca à nível de campo. O método de desidratação químico não apresentou teor de DM ideal para silagem pré-secada, porém, apresentou maior recuperação de fitomassa seca. O maior tempo de desidratação propiciou menores perdas em ambos os métodos de desidratação, mas o método químico não atingiu DM necessária para produção de silagem de qualidade, levando também a uma silagem de menor qualidade.

Palavras-chave: Avena strigosa Schreb. Bromatologia. Cereal de inverno. Forragem conservada. Recuperação de matéria seca.

\section{Introduction}

Livestock chain requires expertise in different activities of the system to succeed. Among them, nutritional management plays a quite important role, demanding high-quality diets to enhance animal productive potential. Thus, pre-dried silage may be an interesting alternative for being of high nutritional value and presenting high fiber digestibility (75\% NDF) and elevated crude protein content (13.2\%) (BOIN et al., 2005). Temperate forages, such as wheat (Triticum aestivum), ryegrass (Lolium multiflorum), and black oat (Avena strigosa Schreb.), are interesting alternatives for this type of ensiling procedure (ROSÁRIO et al., 2012).

Pre-dried silage is so named because has a drying phase in the field, as in hay production. It is necessary because the grass has high levels of humidity in the ideal cutting condition, at preflowering, when forage achieves a balanced dry biomass production per unit area, which is near 6,000 $\mathrm{kg} \mathrm{ha}^{-1}$ (PEREIRA; REIS, 2001), besides a good nutritional quality (BERTO; MÜHLBACH, 1997). Since forage at this stage generally exhibits DM content below 30\%, pre-drying is required for an adequate fermentation process (McDONALD, 1981). In particular, it avoids problems with poor conservation, as the production of effluents and incidence of secondary fermentations (PEREIRA; REIS, 2001). Nonetheless, this material may be exposed to weather changes that can hinder field dewatering, leaching nutrients and losing dry biomass (McDONALD, 1981).

Therefore, it becomes essential the search for a new pre-drying method eliminating dependence on climate and machinery, decreasing production costs and, consequently, obtaining an improved quality material. High plant drying rates can reduce field and fermentation losses, producing a conserved material (PEREIRA; REIS, 2001).

Facing this situation, using glyphosate as chemical dehydration method, for plant drying, may be a promising practice for pre-dried silage production, dewatering plants prior to their cut, and with less dependence on favorable weather conditions.

Among the effects promoted by glyphosate is the alteration in selective permeability of cell membranes that modifies aquaporin functioning and water transport in plant cells, reducing water absorption by plants, besides improving forage quality by variations in the synthesis of plant compounds (ZOBIOLE, 2010; MESCHEDE et al., 2011). Despite being necessary, studies on glyphosate for this purpose are still scarce, precluding a proper recommendation for its use.

Another important factor regarding such use of glyphosate is about forage contamination, which may harm the health of animals and humans consuming contaminated animal products. Krüger at al. (2014), analyzing glyphosate residues in animals and humans, observed that dairy cattle from regions where genetically-modified products are used have higher concentrations of glyphosate in urine $\left(20 \mathrm{ng} \mathrm{ml}^{-1}\right)$ than those regions free of such products $\left(2 \mathrm{ng} \mathrm{ml}^{-1}\right)$. However, Amarante Júnior et al. (2002) claimed that the use of glyphosate is safe because its route of action is non-existent in animals. In addition, the commercial product Roundup Transorb is registered in the Ministry of Agriculture, Livestock, and Supply (MAPA) for 
pre-harvest of black oat as pre-dried silage under number 04299. This means that this product has already undergone rigorous testing for its safe use. Nevertheless, studies involving toxicological reactions in cattle fed glyphosate-treated forage are still rare and its effects are difficult to measure.

Therefore, it is important to know the effects of glyphosate action on black oat (Avena strigosa Schreb) dehydration, regarding phytomass productivity and losses per area, forage chemical composition and suitable dehydration time in the field for pre-dried silaging compared to a mechanical dehydration.

\section{Material and Methods}

The experiment was conducted by the Animal Production Center (NUPRAN), Department of Agricultural and Environmental Sciences, State University of Midwest (UNICENTRO). The study was part of the Master's Degree in Crop Production. The area is located in Guarapuava city, within a subtropical zone of the Paraná state (Brazil), being at the geographical coordinates of $25^{\circ} 23^{\prime} 02^{\prime \prime}$ south latitude, $51^{\circ} 29^{\prime} 43^{\prime \prime}$ west longitude, and 1,026-m altitude.

According to Koppen's classification, local climate is a $\mathrm{Cfb}$ type (mesothermal humid subtropical), with mild summers and winters, without dry season and intense frosts. The average annual rainfall is $1,944 \mathrm{~mm}$, the annual minimum average temperature of $12.7{ }^{\circ} \mathrm{C}$, the annual maximum average temperature of $23.5{ }^{\circ} \mathrm{C}$, and air relative humidity of $77.9 \%$ (IAPAR, 2000). Figure 1 shows the meteorological data during the experimental period and during black oat harvest.

During the experimental period, average rainfall was $81 \mathrm{~mm}$ in May; $163 \mathrm{~mm}$ in June; $16 \mathrm{~mm}$ in July; $18 \mathrm{~mm}$ in August; and $54 \mathrm{~mm}$ in the first 10 days of September. Average values of maximum temperatures were 19.3, 19.2, 19.4, 23.0, and $23.7^{\circ} \mathrm{C}$, and of minimum temperatures were 10.8 ,
$11.2,9.5,9.5$ and 13, for the months of May, June, July, August, and the first 10 days of September, respectively.

The soil in the experimental was classified as typical bruno Latosol (i.e. Oxisol) (POTT et al., 2007). Soil liming was performed according to requirements of a previous analysis. The soil chemical characteristics upon experiment time were $\mathrm{pH}$ of 4.7 ; OM of $2.62 \%$; P of $1.1 \mathrm{mg} \mathrm{dm}^{-3}$; $\mathrm{K}^{+}$of $0.2 \mathrm{cmol} \mathrm{dm}^{-3} ; \mathrm{Al}^{3+}$ of $0.0 \mathrm{cmol} \mathrm{dm}{ }^{-3} ; \mathrm{H}^{+}+\mathrm{Al}^{3+}$ of 5.2 $\mathrm{cmol} \mathrm{dm}{ }^{-3} ; \mathrm{Ca}^{+2}$ of $5.0 \mathrm{cmol} \mathrm{dm}{ }^{-3} ; \mathrm{Mg}^{2+}$ of $5.0 \mathrm{cmol}$ $\mathrm{dm}^{-3}$ and base saturation of $67.3 \%$.

The experimental area was prepared with the aid of a chisel plow and a harrow disc. Black oat (Avena stringosa Schreb) of cultivar EMBRAPA 139 was grown according to the agricultural zoning for Guarapuava region, in Paraná state (Brazil). Sowing was carried out on May 19, 2014, using a towed seeder (Semeato SHM 15/17), with rows spaced in $17 \mathrm{~cm}$ and sowing at a depth of $4 \mathrm{~cm}$, and at a sowing density of 400 seeds per $\mathrm{m}^{2}$. The experimental area was of $867 \mathrm{~m}^{2}$ divided into 5 blocks, with 12 plots each, in a total of 60 plots of $14.45 \mathrm{~m}^{2}(2.89 \mathrm{~m} \times 5.00 \mathrm{~m})$.

Fertilization at time-of-planting was made with NPK fertilizer using $300 \mathrm{~kg} \mathrm{ha}^{-1}$ of the formulation 08-30-20 (N-P203-K20), as recommended by the Soil Fertility Commission of Santa Catarina and Rio Grande do Sul States (TEDESCO et al., 2004). Nitrogen fertilization was applied 30 days after crop emergence (DAE) as topdressing with urea (46-00-00), totalizing $120 \mathrm{~kg}$ nitrogen per ha, in a single dose. All crop husbandry practices were also performed according to the technical recommendations for oat cropping (CARVALHO; STRACK, 2014).

Oat plant stand was of 220 thousand plants per ha, with an average height of $0.8 \mathrm{~m}$ and a tiller number of 946.1 thousand per ha. These numbers were estimated by counting in $0.25 \mathrm{~m} \times 0.25 \mathrm{~m}$ squares. 
Figure 1. Sunlight, relative humidity, rainfall, and maximum and minimum temperatures during the oat dehydration period in the field, provided by the meteorological station of IAPAR, set at the CEDETEG / UNICENTRO, Guarapuava $-\mathrm{PR}$.
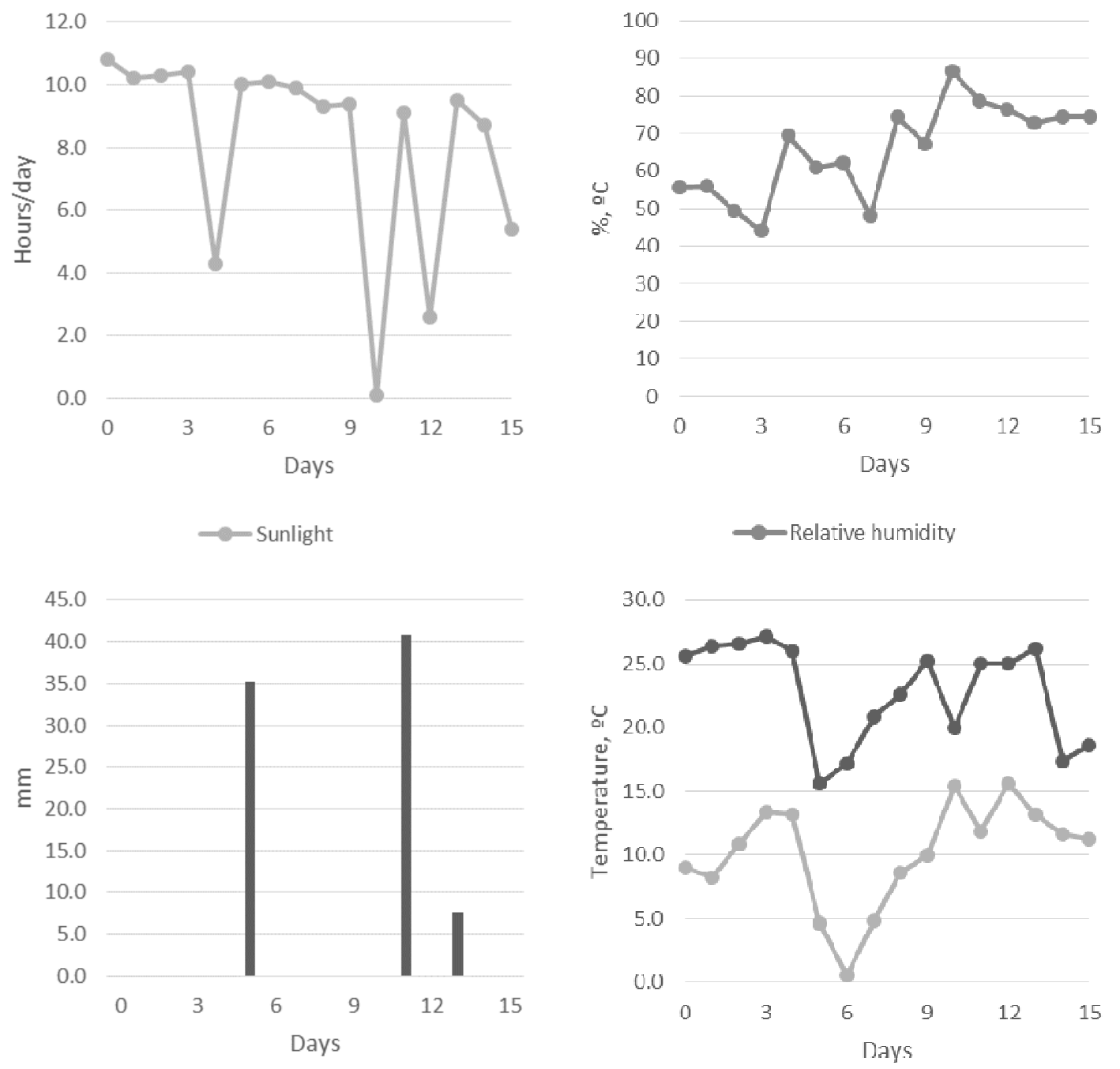

The experiment was carried out in a completely randomized block design arranged in 2 x 6 factorial scheme. Treatments were composed of two forage dehydration methods (chemical and mechanical) and six harvest times $(0,3,6,9,12$, and 15 days), with five replicates. Chemical dehydration was made by applying Roundup Transorb herbicide (glyphosate) at a dose of $0.5 \mathrm{~L} \mathrm{ha}^{-1}$, and plants were cut only at the time of harvest for ensiling. Whereas the mechanical one was carried out by exposing plants to climatic conditions in the field from cutting time until harvest when they were cut using hand scythes.
Harvests were performed after $0,3,6,9,12$, and 15 days of field dehydration, totaling 6 dehydration times. Dehydration time is the period between the use of the dehydration method of the plot and its harvest to ensilage. At day 0 , forage was cut and ensiled soon after for mechanical dehydration. For chemical dehydration, right after herbicide application, fodder was harvested, which was always made at 01 h30 p.m., on the previously stipulated days. 
The first evaluation was accomplished on August 21, 2014. By this time, plants had been at 88 DAE, i.e. at the pre-flowering stage when 30 plots were fully harvested, cutting plants at $8 \mathrm{~cm}$ height from the soil, using a hand scythe. These cut plots referred to the mechanical dehydration treatment. For the other 30 plots, an application of herbicide with the active ingredient glyphosate referred to the chemical treatment.

Herbicide was applied using an electric backpack sprayer equipped with a four-nozzle boom, set to achieve a flow rate of $200 \mathrm{~L} \mathrm{ha}^{-1}$. Spraying took place at $05 \mathrm{~h} 00$ p.m. under sunlight and relative humidity of $35 \%$ and temperature of $21^{\circ} \mathrm{C}$, without rainfall occurrence.

Total plot material was weighed each harvest day for fresh phytomass calculation. Hereupon, a homogeneous sample was collected (400 g) for plant dry matter estimation (PDM), according to the method proposed by Jobim et al. (2007).

Forage samples were placed in forced aircirculation oven at $55^{\circ} \mathrm{C}$ for 72 hours or until constant weight for estimation of partial DM and further dry phytomass production (DPP). Other samples were physically separated into stems and leaves, which were then taken to drying in the same oven for determinations of stem dry matter (SDM) and leaf dry matter (LDM) and leaf ratio (L/W). A 9-g sample was used for $\mathrm{pH}$ measurement using a digital potentiometer. For dry phytomass recovery, calculations were made by the difference from time- 0 dry phytomass and the values found in each assessed period so recovery could be ascertained.

The total amount of forage of each plot was chopped in a stationary forage machine (Nogueira, EM 6400) to an average particle size of $2 \mathrm{~cm}$. This chopped material remained in experimental silos made of PVC (polyvinyl chloride), with $10 \mathrm{~cm}$ diameter and $45 \mathrm{~cm}$ length. The chopped black oat forage was manually pressed with the help of an iron bar at standardized compaction pressures from 220

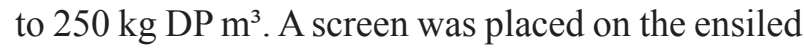

material, and a plastic bag sealed the silo inlet, preventing the entry of air and exit of any produced effluent for further quantification. Sealing was completed with adhesive tape. After 60 days under a cool environment without luminosity, produced effluents were drained from the plastic bags with the assistance of a syringe for quantification (EP), thereafter the silos were open and 300-g samples were collected for bromatological analysis.

Three-hundred-gram samples were taken to drying in the forced air oven at $55{ }^{\circ} \mathrm{C}$ for 72 hours or until reach constant weight for partial DM determination. Later, 9-g samples were withdrawn for $\mathrm{pH}$ measurement $(\mathrm{pH})$ using a digital potentiometer. Thereafter each sample was ground in a Wiley mill with a 1-mm mesh sieve and then packed in plastic bags for further chemical analysis. Samples of the whole plant underwent the same process.

For bromatological analysis, the samples were placed in an oven at $105^{\circ} \mathrm{C}$ for 4 hours for total DM measurement (SILVA; QUEIROZ, 2009). Crude protein $(\mathrm{CP})$ was estimated by the micro-Kjeldahl method and mineral matter (MM) by incinerating the dry matter at $550{ }^{\circ} \mathrm{C}$ for 4 hours, with the rules of the AOAC (1995).

Contents of neutral detergent fiber (NDF) were determined according to the method described by Van Soest et al. (1991), and contents of acid detergent fiber (ADF) by the method of Goering and Van Soest (1970). Yet acid detergent lignin (LIG) was assessed using acid digestion method by Klasson (SILVA; QUEIROZ, 2009).

The experimental design was randomized block in a two-factor arrangement $(2 \times 6)$, which consisted of two forage dehydration methods (chemical and mechanical) and six harvest times (0, 3, 6, 9, 12, and 15 days after dehydration), with five replications. Once normality and homogeneity assumptions were established, results underwent variance analysis and means were compared using the "ProcReg" procedure at $5 \%$ significance through the statistical program SAS (1993). 


\section{Results and Discussion}

Table 1 shows that there was a significant interaction between dehydration methods and times $(\mathrm{p}=0.0001)$ regarding dry matter production (DPP) and dry phytomass recovery (DPR).

According to Figure 2, DP production decreased linearly to a rate of $181.70 \mathrm{~kg} \mathrm{ha}^{-1}$ a day ( $\mathrm{p}=$ 0.0001) using the mechanical method, while the chemical one had a positive quadratic behavior with a production peak on day 7 . DPR presented a decreasing linear behavior for the mechanical method $(p=0.0001)$, with a drop of $2.62 \%$ per dehydration day. However, the chemical method had a positive quadratic effect $(\mathrm{P}=0.0210)$, with a recovery peak on day 7 of dewatering time.

Zobiole (2010) reported that glyphosate plays a role on the selective permeability of cell membranes, with consequent changes in the activity of aquaporins, which leads to alterations in water transport within cells, thus reducing the absorption of water by the plant. Silva et al. (2015) observed an increasing stomatal conductance and transpiration by application of glyphosate at dosages of $0.45 \mathrm{ha}^{-1}$ $\mathrm{L}$; this fact may add to the loss of water by plants.

Table 1. Summary of the analysis of variance of the average values of DPP (dry phytomass production, $\mathrm{kg} \mathrm{ha}^{-1}$ ), DMR (dry phytomass recovery, $\mathrm{kg} \mathrm{ha}^{-1}$ ), PDM (plant dry matter at harvest, \%), SDM (stem dry matter, \%), LDM (leaf dry matter, \%), SiDM (silage dry matter, \%), SiDPR (silage dry phytomass recovery, \% ), EP (effluent production, $\mathrm{L} \mathrm{m}^{-3}$ ), pHp (plant pH), pHs (silage pH), MM (mineral matter, \% DM), CP (crude protein, \% DM), NDF (neutral detergent fiber, \% DM), ADF (acid detergent fiber, \% DM) and LIG (lignin, \% DM) of pre-dried oat by mechanical and chemical method, and associated to different dehydration times.

\begin{tabular}{ccccccc}
\hline \multirow{2}{*}{ Parameter } & \multicolumn{3}{c}{ Dehydration methods } & \multicolumn{3}{c}{ Probability $(\mathrm{P}<0.05)$} \\
\cline { 2 - 7 } & Chemical & Mechanical & Error & $\mathrm{D}$ & $\mathrm{T}$ & $\mathrm{D}^{*} \mathrm{~T}$ \\
\hline DPP $\left(\mathrm{kg} \mathrm{ha}^{-1}\right)$ & 6,532 & 5,403 & $300,957.14$ & 0.0001 & 0.0001 & 0.0001 \\
DPR (\%) & 102.7 & 78.2 & 58.4552 & 0.0001 & 0.0001 & 0.0001 \\
PDM (\%) & 19.83 & 36.17 & 1.7548 & 0.0001 & 0.0001 & 0.0001 \\
SDM (\%) & 18.43 & 34.74 & 4.6273 & 0.0001 & 0.0001 & 0.0001 \\
LDM (\%) & 30.09 & 56.88 & 9.4049 & 0.0001 & 0.0001 & 0.0001 \\
SiDM (\%) & 19.25 & 35.47 & 1.5371 & 0.0001 & 0.0001 & 0.0001 \\
SiDPR (\%) & 97.48 & 97.36 & 3.0018 & 0.7903 & 0.0001 & 0.1652 \\
EP (L m $\left.{ }^{3}\right)$ & 10.01 & 7.90 & 105.2825 & 0.4315 & 0.0001 & 0.0894 \\
pHP & 5.9 & 6.2 & 0.0101 & 0.0001 & 0.0001 & 0.0001 \\
pHS & 4.39 & 4.78 & 0.0406 & 0.0001 & 0.0001 & 0.0018 \\
MM (\% DM) & 5.36 & 5.65 & 0.1117 & 0.0366 & 0.0001 & 0.0010 \\
CP (\% DM) & 9.38 & 10.42 & 0.7647 & 0.0002 & 0.1030 & 0.0010 \\
NDF (\% DM) & 60.40 & 60.44 & 12.1413 & 0.6606 & 0.0022 & 0.0736 \\
ADF (\% DM) & 38.55 & 38.19 & 3.4027 & 0.5751 & 0.0001 & 0.0031 \\
LIG (\% DM) & 6.06 & 5.63 & 1.2166 & 0.0770 & 0.3089 & 0.1808 \\
\hline
\end{tabular}


Figure 2. Dry phytomass production (DPP) and recovery (DPR) at the pre-drying of oat silage, dehydrated by mechanical and chemical methods associated with different dehydration times.

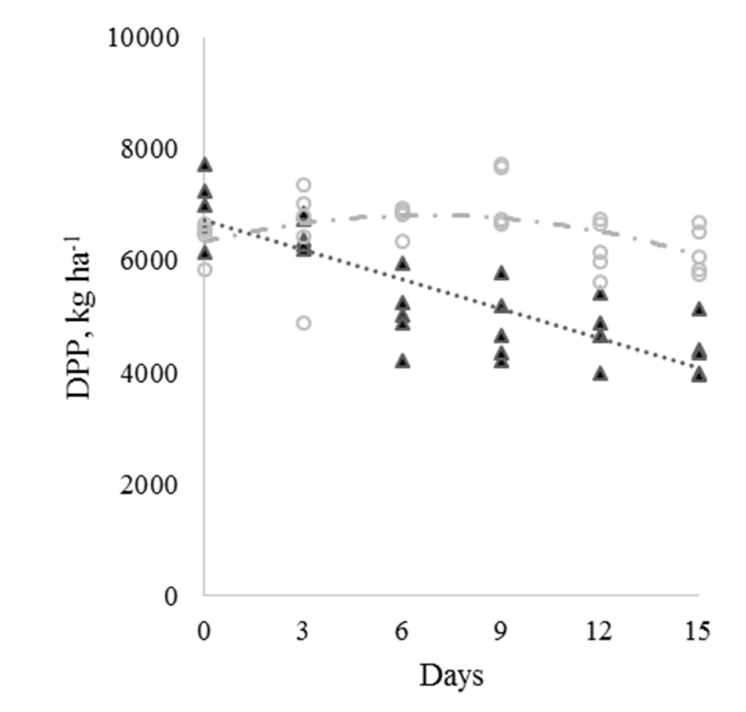

\section{........ Mechanical - - Chemical}

DPPm: 6796.3512-181.7023D

(CV: $\left.11.6 \% ; \mathrm{R}^{2}: 0.682 ; \mathrm{p}=0.0001\right)$

DPPc: $6189.8367+178.4984 \mathrm{D}-12.4091 \mathrm{D}^{2}$

(CV: $\left.8.5 \% ; \mathrm{R}^{2}: 0.192 ; \mathrm{p}=0.0560\right)$

DPP of both treatments was superior to those found by Ferolla et al. (2007). These authors reported DPP of up to $3,426 \mathrm{~kg} \mathrm{ha}^{-1}$ for three black oat harvests, in the state of Rio de Janeiro. On the other side, the values found here were lower than were those observed by Floss et al. (2007), who registered 9,151 kg ha-1 for white oat cut at $98 \mathrm{DAE}$, in the state of São Paulo. It is noteworthy that these studies evaluated only DPP at the time of cutting, without assessing forage dehydration for silage. Also in this parameter, chemical dehydration had higher values than the mechanical method. Interestingly, there was an increase in this parameter, even after herbicide application. This may occur because of the absence of field losses as leaf detachment from plant stem, or inefficient forage gathering that is solved by chemical desiccation, in which plant is only cut at harvest time. Another possibility might be due to the glyphosate dosage being smaller than the conventional for drying $\left(4.5 \mathrm{~L} \mathrm{ha}^{-1}\right)$; therefore, the plant might have accumulated DP after application, showing a delay in a photosynthetic capacity reduction by glyphosate at $0.5 \mathrm{~L} \mathrm{~h}^{-1}$.

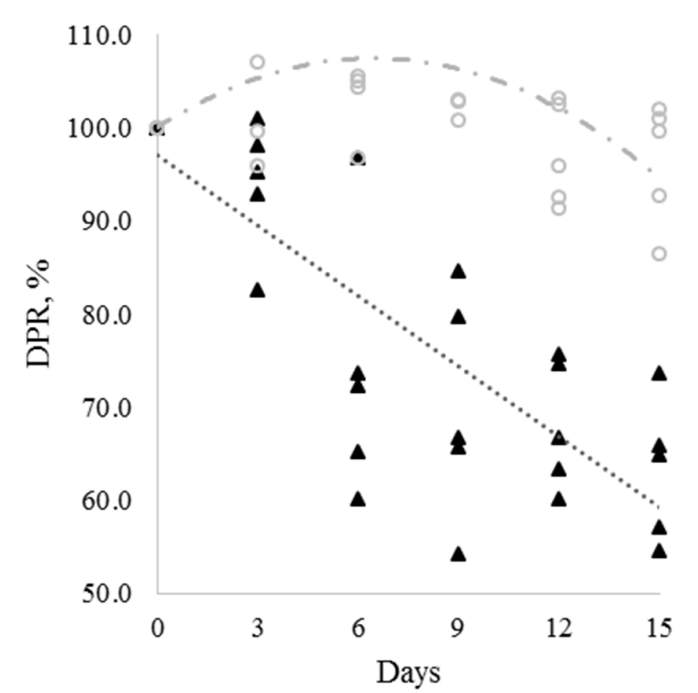

DPRm: 98.2866-2.6179D

(CV: 12.7\%; R $\left.\mathrm{R}^{2}: 0.641 ; \mathrm{p}=0.0001\right)$

DPRc: $98.1519+2.7298 \mathrm{D}-0.1984 \mathrm{D}^{2}$

(CV: 7.7\%; $\left.\mathrm{R}^{2}: 0.249 ; \mathrm{p}=0.0210\right)$.

The superior values of DPR observed in the chemical method are closely related to the DP production. This may indicate that when DP and DPR are evaluated separately, the chemical method stands out, revealing higher results if compared to the mechanical one, as seen in the present study. As for DP, the greater DPR in chemical treatment can be justified by the reduced loss of material in the field at harvest, by plant stress due to cutting, and by DP losses during dehydration, which was higher in the mechanical method. At the time of cutting, there was an abrupt interruption of water supply to the plants, triggering a number of physiological responses for plant balance. This process leads to continued intake of nutrients by the plant due to its breathing, thus reducing DPR of forage (TAIZ; ZEIGER, 2004).

Table 1 highlights that PDM, SDM, and LDM showed a significant interaction of dehydration methods with times. Figure 3 illustrates the trend lines for the above-mentioned variables. PDM had an increase of $2.04 \%$ per day when using the 
mechanical method $(\mathrm{p}=0.0001)$, and $0.7 \%$ increase with the chemical one $(p=0.0001)$, whereas SDM increased $0.5 \%$ a day in both methods $(p=0.0001)$. For LDM, the increment was $3.8 \%$ a day using the mechanical method $(p=0.0001)$ and of $2.01 \%$ through the chemical dehydration $(\mathrm{p}=0.0001)$. Furthermore, the trend lines demonstrated that there was a great influence of SDM on PDM since both presented similar values.

Figure 3. Average levels of dry matter of plants (PDM), stem (SDM), and leaves (LDM) at the pre-drying of oat silage, dehydrated by mechanical and chemical methods, associated with different dehydration times.
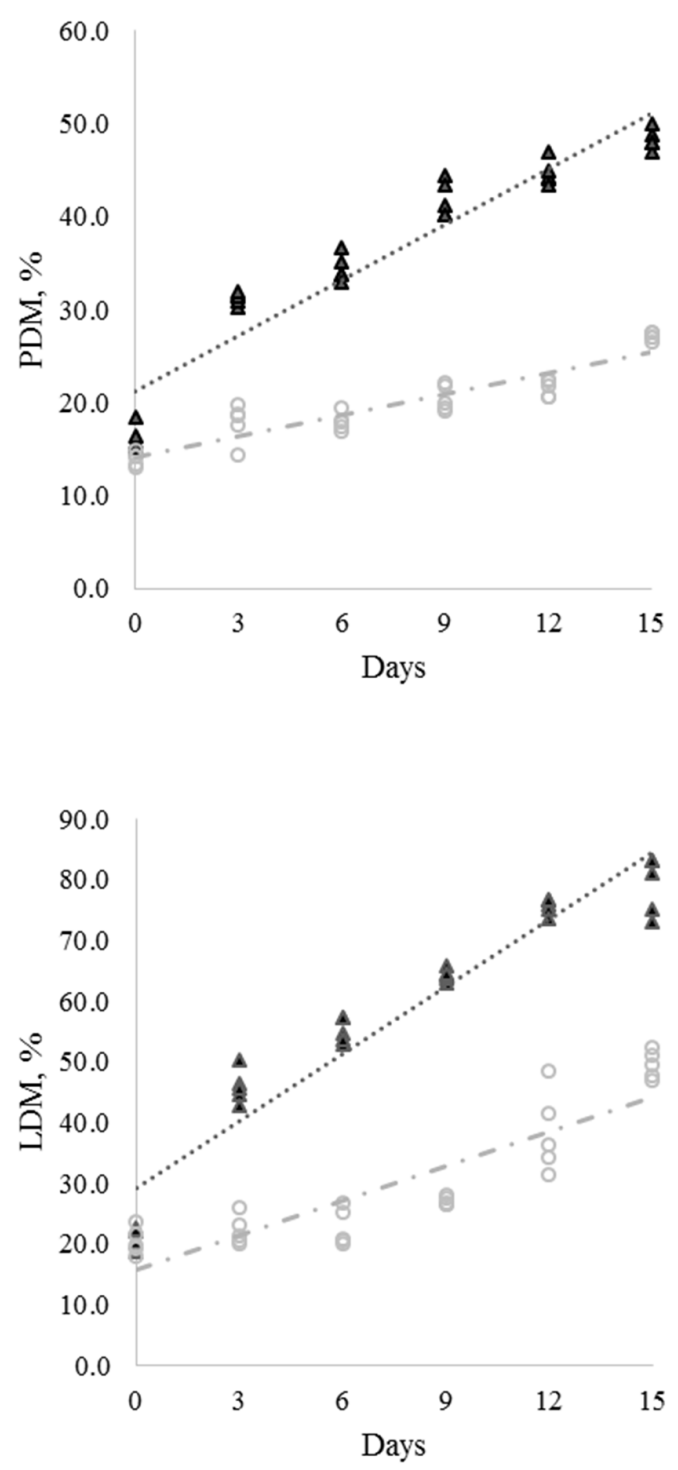

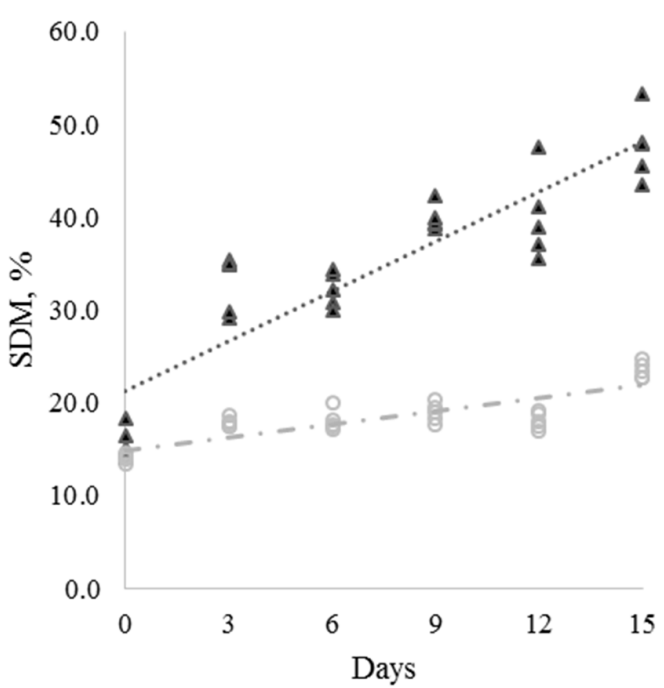

PDMm: 20.4878+2.0449D

$\left(\mathrm{CV}: 11.1 \% ; \mathrm{R}^{2}: 0.869 ; \mathrm{p}=0.0001\right)$

PDMc: $13.7461+0.7934 \mathrm{D}$

$\left(\mathrm{CV}: 8.49 \% ; \mathrm{R}^{2}: 0.8504 ; \mathrm{p}=0.0001\right)$

SDMm: $20.6370+1.8405 \mathrm{D}$

(CV: $\left.14.8 \% ; \mathrm{R}^{2}: 0.767 ; \mathrm{p}=0.0001\right)$

SDMc: $14.7416+0.4807 \mathrm{D}$

(CV: 9.2\%; R : $0.671 ; p=0.0001)$

LDMm: 27.7432+3.8006D

(CV: $\left.11.7 \% ; \mathrm{R}^{2}: 0.893 ; \mathrm{p}=0.0001\right)$

LDMc: $14.6831+2.0092 \mathrm{D}$

(CV: $\left.16.8 \% ; \mathrm{R}^{2}: 0.801 ; \mathrm{p}=0.0001\right)$

........ Mechanical - - Chemical
Chemical dehydration was inefficient to increase PDM to an ideal content for pre-dried silage production. Values below 40\% DM silage are unable of inhibiting unwanted bacteria, promoting an inefficient storage of pre-dried forage, which reaches high $\mathrm{pH}$ (NISHINO et al., 2011). There might have been a minor activity of glyphosate during dehydration time driven by adverse weather conditions with rainfalls, as well as the use of a suboptimal glyphosate dose for oat dehydration. Coan 
et al. (2001) obtained a PDM of $32.3 \%$ in oat silage mechanically dehydrated for six hours.

Stomata remain open for one hour after forage cutting. After that, water loss is basically by cuticular evaporation, which is a slow phase of plant dehydration (PEREIRA; REIS, 2001). Glyphosate can have a negative effect on stomata, causing them to close (YANNICCARI et al., 2012). This statement may explain why mechanical dehydration was superior concerning plant water loss, which was confirmed by higher DM contents of stem and leaf in this treatment.

With the development of forage, there was a reduction in leaf/ stem ratio, resulting in nutrient loss due to an increasing plant fiber content. The more developed the plant, the shorter the dehydration time in the field, since it will have a higher MS content. On the other hand, grass leaves lose water 15 times faster than do the stems; yet, $25 \%$ stem moisture is lost through leaf evaporation (PEREIRA; REIS, 2001).

Table 1 shows the analysis of variance for silage dry matter (SiDM), silage dry phytomass recovery (SiDPR) and effluent production (EP). For SiDM, there was a significant interaction between methods and times $(p=0.0001)$. DMR had no significant interaction ( $p=0.1652)$, as well as EP $(p=0.0894)$. As shown in Figure 4, SiDM contents showed a linear increase with of $1.91 \%$ for the mechanical method, and of $0.83 \%$ for the chemical one. Even though SiDPR showed no difference among treatments, it showed a rising linear midline $(p=0.0001)$ with an increase of $0.31 \%$ per day. The chemical method showed an EP with negative quadratic behavior ( $p$ $=0.0002$ ), and the lowest production after 13 days. The mechanical method showed decreasing linear effect $(p=0.0008)$, showing a drop of $2.18 \mathrm{~L} \mathrm{~m}^{-3}$ per day.
The mechanical dehydration showed higher DM contents in the field, so silages of this treatment reached $45 \% \mathrm{DM}$ at harvest made 15 days after the cut, while the chemical one reached only $26.44 \%$ within the same period. Based on this, we assumed that glyphosate could not provide a silage with optimum dry matter content for pre-dried silage, resulting in unwanted fermentations with effluent losses (ZAMARCHI et al., 2014).

By harvesting oat at flowering stage through mechanical dewatering of 6 hours under the sunlight, Paris et al. (2015) found a silage with $24.36 \%$ DM. Conversely, after three days of glyphosate application (0.5 L ha-1), Bueno (2015) obtained oat silage with $37.6 \% \mathrm{DM}$ at reproductive stage, thus being considered the best treatment for this parameter.

According to Jobim et al. (2007), SiDPR is calculated by the difference between initial and final gross dry matter, from silos in relation to the amount of ensiled forage. Such difference derives from losses during the fermentation process, such as the production of gases and effluents. Therefore, with the increasing DM in silage, there was also an increment in SiDPR, what, according to McDonald (1981), is because the increase in silage dry matter inhibits fermentation as a whole, preserving most of the herbage nutrient content and increasing SiDPR.

Effluents are produced in silage due to a rupture of cell walls, causing them to pour out the cellular content. This occurs frequently in silages with high moisture content. Here, it was clear in treatments under mechanical dehydration, shortening the period of EP. Unlike, the chemical method prolonged the time of EP. Moreover, EP indicates loss of DP, as well as a reduction in silage nutritional value, besides being a water pollutant (GEBREHANNA et al., 2014). 
Figure 4. Average levels for silage dry matter (SiDM), silage dry phytomass recovery (SiDPR), and effluent production (EP) at the pre-drying of oat silage, dehydrated by mechanical and chemical methods, associated with different dehydration times.
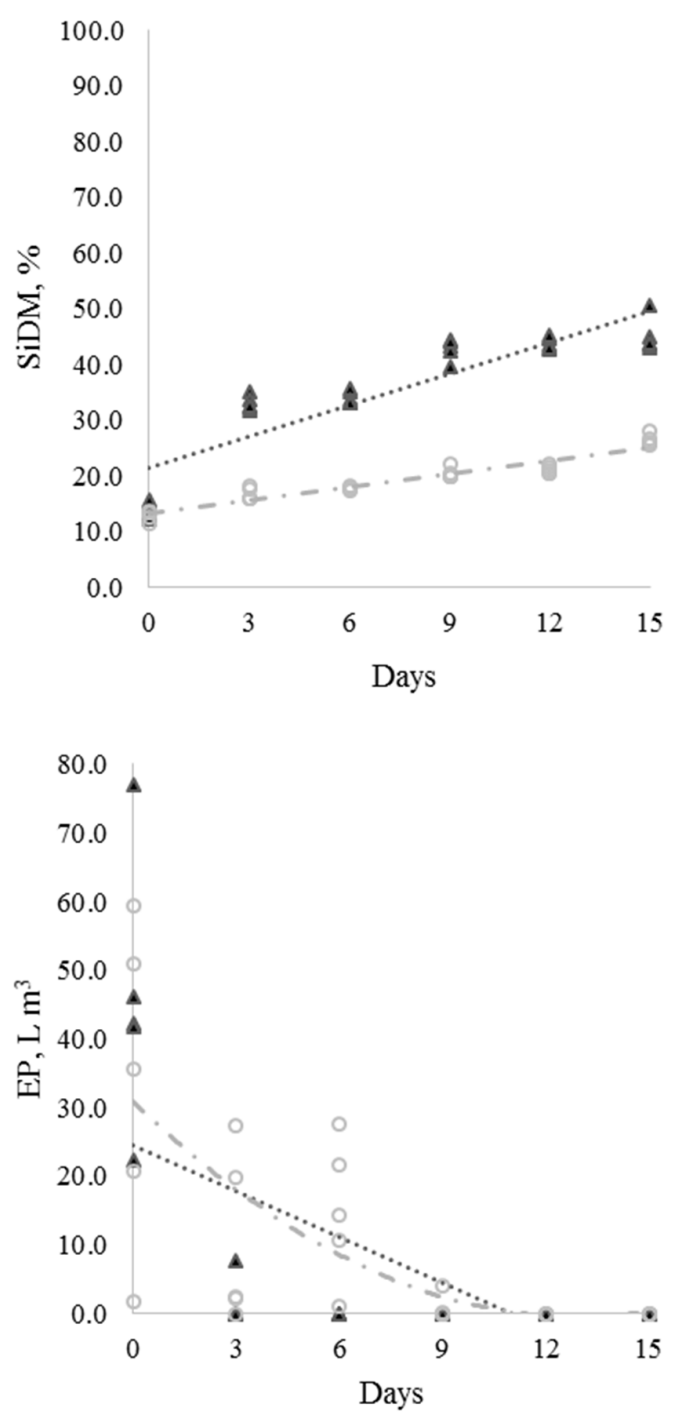

In addition, Table 1 also denotes a significant interaction for $\mathrm{pH}$ of plant parameters (pHP) and of silage (pHS) between times and methods of dehydration. Figure 5 displays an increasing linear behavior of $\mathrm{pHP}$, both for the mechanical $(\mathrm{p}=$ $0.0001)$ and for chemical $(p=0.0001)$ methods, with $\mathrm{pH}$ rises of 0.1 and 0.05 units, respectively. However, pHS had a negative quadratic behavior for the mechanical method $(\mathrm{p}=0.0395)$ and for the chemical one $(\mathrm{p}=0.0001)$, with the lowest $\mathrm{pH}$ estimated on day 8 and day 14 days, respectively.

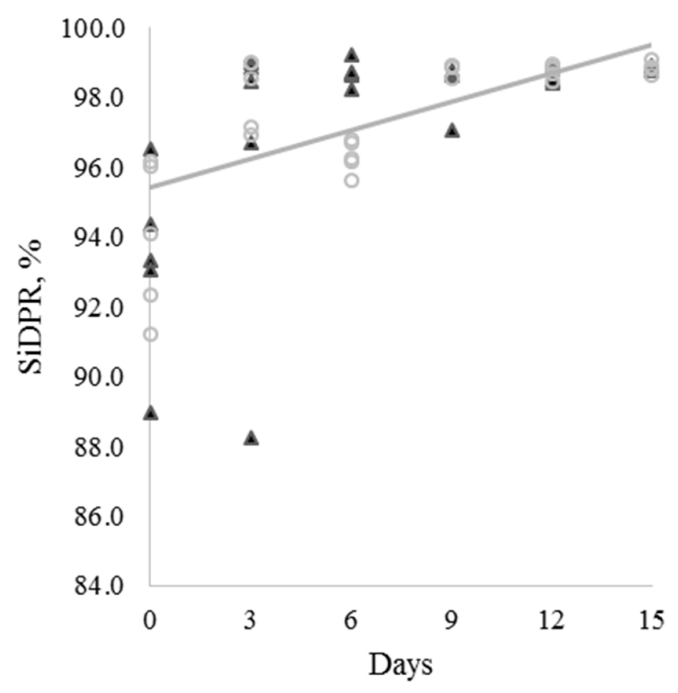

SiDMm: 20.8032+1.9133D

(CV: 16.0\%; R : 0.744; $\mathrm{p}=0.0001)$

SiDMc: $12.9139+0.8262 \mathrm{D}$

(CV: 7.2\%; R : 0.902; $\mathrm{p}=0.0001)$

SiDPR: $95.0649+0.3068 \mathrm{D}$

(CV: 2.04\%; R : 0.371; $\mathrm{p}=0.0001)$

EPm: 24.6607-2.1853D

(CV: 197.9\%; $\left.\mathrm{R}^{2}: 0.333 ; \mathrm{p}=0.0008\right)$

EPc: $34.4005-5.5333 \mathrm{D}+0.2181 \mathrm{D}^{2}$

(CV: $\left.120.7 \% ; R^{2}: 0.478 ; p=0.0002\right)$

........ Mechanical - - Chemical - Average

There was a wider range of $\mathrm{pHP}$ compared to $\mathrm{pHS}$, with the longest dehydration. It may explain the fact that a silage with higher dry matter contents can promote higher $\mathrm{pH}$ drops from the initial value, indicating an improved fermentation of ensiled mass (ZAMARCHI et al., 2014). David et al. (2010) reported $\mathrm{pH}$ of 4.7 in oat silage cut at the early flowering stage.

Jobim et al. (2007) stated that, in pre-dried silages, $\mathrm{pH}$ is usually above 4.2 , which goes against the findings of our study. This is because 
these silages have low moisture, where there is a greater mass buffering action and somewhat soil contamination during dehydration process in the field. This can be observed in this study, wherein the silage from chemical method presented lower levels of pHS because they had higher moisture contents, being solely cut at harvest time so avoiding soil contamination. Thus, it may consist of a positive point for silages dehydrated by the chemical method.

Figure 5. Values of $\mathrm{pH}$ of plant (pHP) and silage $\mathrm{pH}(\mathrm{pHS})$ at the pre-drying of oat silage, dehydrated by mechanical and chemical methods, associated with different dehydration times.
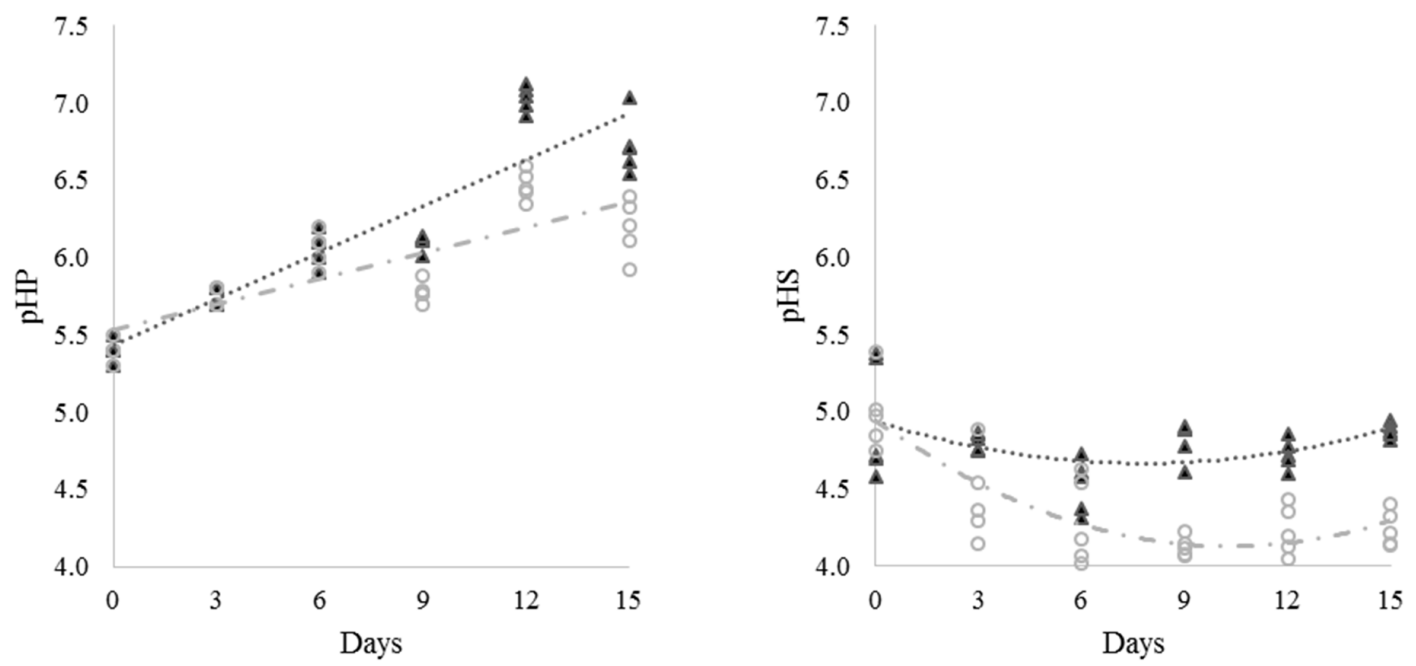

\section{........ Mechanical - - Chemical}

pHPm: $5.3848+0.1024 \mathrm{D}\left(\mathrm{CV}: 4.0 \% ; \mathrm{R}^{2} ; 0.819 ; \mathrm{p}=0.0001\right)$

pHPc: $5.5112+0.056 \mathrm{D}\left(\mathrm{CV}: 3.6 \% ; \mathrm{R}^{2}: 0.670 ; \mathrm{p}=0.0001\right)$

pHSm: 4.9976-0.0830D+0.0051D $\left(\mathrm{CV}: 4.2 \% ; \mathrm{R}^{2}: 0.213 ; \mathrm{p}=0.0395\right)$

pHSc: $5.3399+0.1263 \mathrm{D}-0.0044 \mathrm{D}^{2}$ (CV: 4.9\%; $\mathrm{R}^{2}: 0.639 ; \mathrm{p}=0.0001$ ).

Moreover, Bueno (2015) obtained an average $\mathrm{pH}$ of 3.8 in silage of wilted black oat with the application of $0.5 \mathrm{~L} \mathrm{ha}^{-1}$ glyphosate, highlighting that silages were inoculated with Lactobacillus plantarum and Pediococcus acidilactici. Jacobs et al. (2009) showed average values of 5.0 for pHS in dehydrated silages, and of 4.5 in non-dehydrated silages; these authors stated that dehydrated silage ferments less than do non-dehydrated ones.

Table 1 shows the significant interactions of the parameters mineral matter $(\mathrm{MM})(\mathrm{p}=0.0010)$ and crude protein $(C P)(p=0.0010)$. As shown in Figure 6, MM of the silages mechanically dewatered showed a negative quadratic effect $(\mathrm{P}=0.0001)$, while those under chemical treatment had a positive quadratic effect $(\mathrm{P}=0.0001)$. Meanwhile, $\mathrm{CP}$ content of the silage from chemical method presented equations with negative quadratic behavior $(p=0.0001)$ with the lowest values estimated on day 12 , while silages treated with the mechanical method presented equations with quadratic positive behavior ( $\mathrm{p}=$ $0.0001)$, with peak values estimated on day 8 .

During silage fermentation, as soluble compounds are consumed, the content of lowmobility compounds increases, such as minerals, because it is a stoichiometric relation, increasing, thus, its participation in the dry matter (FERREIRA et al., 2007). Therefore, chemical dehydration method was able to decrease the content of MM in silages, showing the ability of this method to control fermentation to retaining soluble compounds, improving silage nutritional quality. 
Figure 6. Average values of mineral matter $(\mathrm{MM})$ and crude protein $(\mathrm{CP})$ at the pre-drying of oat silage, dehydrated by mechanical and chemical methods, associated with different dehydration times.

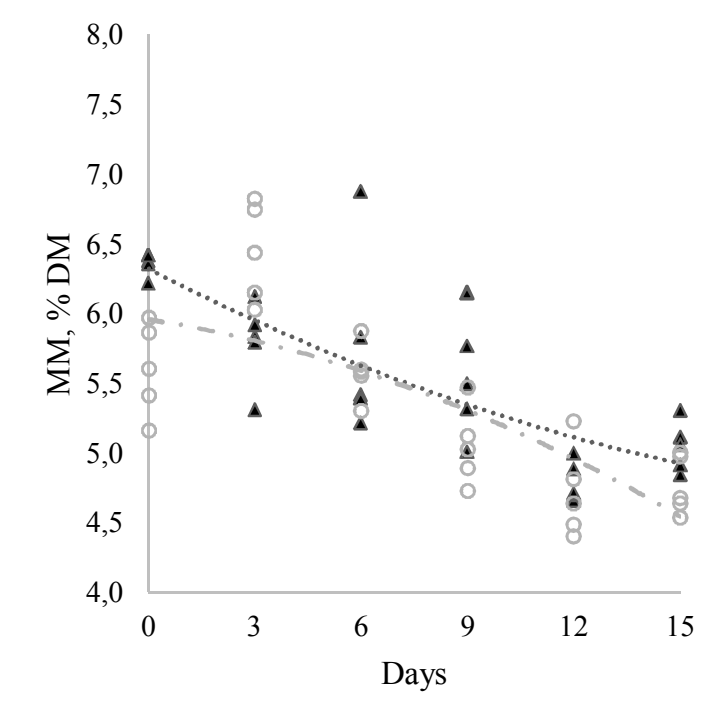

........ Mechanical - - Chemical

MMm: 6.4338-0.1544D+0.0037D 2

(CV: $\left.7.1 \% ; \mathrm{R}^{2}: 0.618 ; \mathrm{p}=0.0001\right)$

MMc: $6.1107-0.0880 \mathrm{D}-0.0008 \mathrm{D}^{2}$

(CV: $8.2 \% ; \mathrm{R}^{2}: 0.585 ; \mathrm{p}=0.0001$ )

Nevertheless, chemical dehydration decreased CP contents in silages. Orcaray et al. (2012) explained this by saying that glyphosate is able to reduce crude protein in plants because it acts on the shikimic acid so that plants can no longer fix exogenous nitrogen and, thus, inhibiting the production of essential aromatic amino acids. Rains may also decrease plant CP contents since they enhance the leaching of nutrients, what may be seen in both methods.

NDF and LIG showed no significant interaction between dehydration methods and times ( $\mathrm{p}=$ 0.0736 and 0.1808 , respectively); on the contrary, ADF presented a significant interaction $(p=0.0031)$ (Table 1). Figure 7 shows NDF increased with the advance of dehydration time. This parameter showed a negative quadratic behavior $(p=0.0112)$, with the smallest value on day 5. For ADF, equations showed a negative quadratic behavior for both treatments with a lower concentration of this fraction after day 8 for the mechanical method $(p=0.05)$ and after day 9 for the chemical one $(p=0.0001)$. LIG showed no

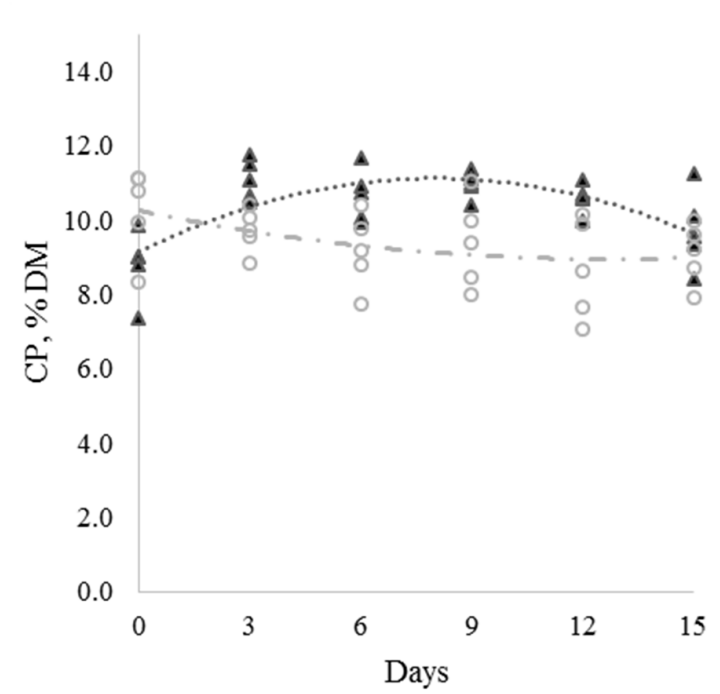

CPm: $8.8096+0.5571 \mathrm{D}-0.0335 \mathrm{D}^{2}$

(CV: $\left.7.9 \% ; \mathrm{R}^{2}: 0.422 ; \mathrm{p}=0.0006\right)$

CPc: $9.38 \%$

$\left(\mathrm{CV}: 10.8 \% ; \mathrm{R}^{2}: 0.189 ; \mathrm{p}=0.0591\right)$.

significant equation keeping an average of $5.8 \%$ for both treatments.

The increase in NDF and ADF observed in our study might have been caused by the occurrence of rains during the dehydration process in the field, decreasing the amount of nutrients, as well as CP and non-fiber carbohydrates, besides a consequent increase of fiber fractions.

Zamarchi et al. (2014), in an experiment with oat, ensiled fodder after 6 hours of dehydration and obtained NDF values of $66.69 \%$ and ADF of 38.36 . Yet, Paris et al. (2015), in an experiment with oat silage cut in the early flowering and dehydrated by a mechanical method, obtained NDF of $55.8 \%$ and $\mathrm{ADF}$ of $37.21 \%$, which are values lower than were the ones we found in this study. Those authors highlighted that the low production of effluents was due to forage dehydration, limiting losses of soluble compounds and preventing the increase in fiber fractions. The content of LIG obtained by Meinerz et al. (2011) was $4.42 \%$, being lower compared to 
that found in this study. David et al. (2010) obtained values of $5.8 \%$ for LIG in silage from oats harvested in the early flowering. As claimed by Meinerz et al.
(2011), LIG is directly related to the digestibility of forage since this fraction is quite indigestible, therefore, the higher the lignin content, the lower the forage digestibility.

Figure 7. Average values of neutral detergent fiber (NDF), acid detergent fiber (ADF), and lignin (LIG) at the predrying of oat silage, dehydrated by mechanical and chemical methods, associated with different dehydration times.
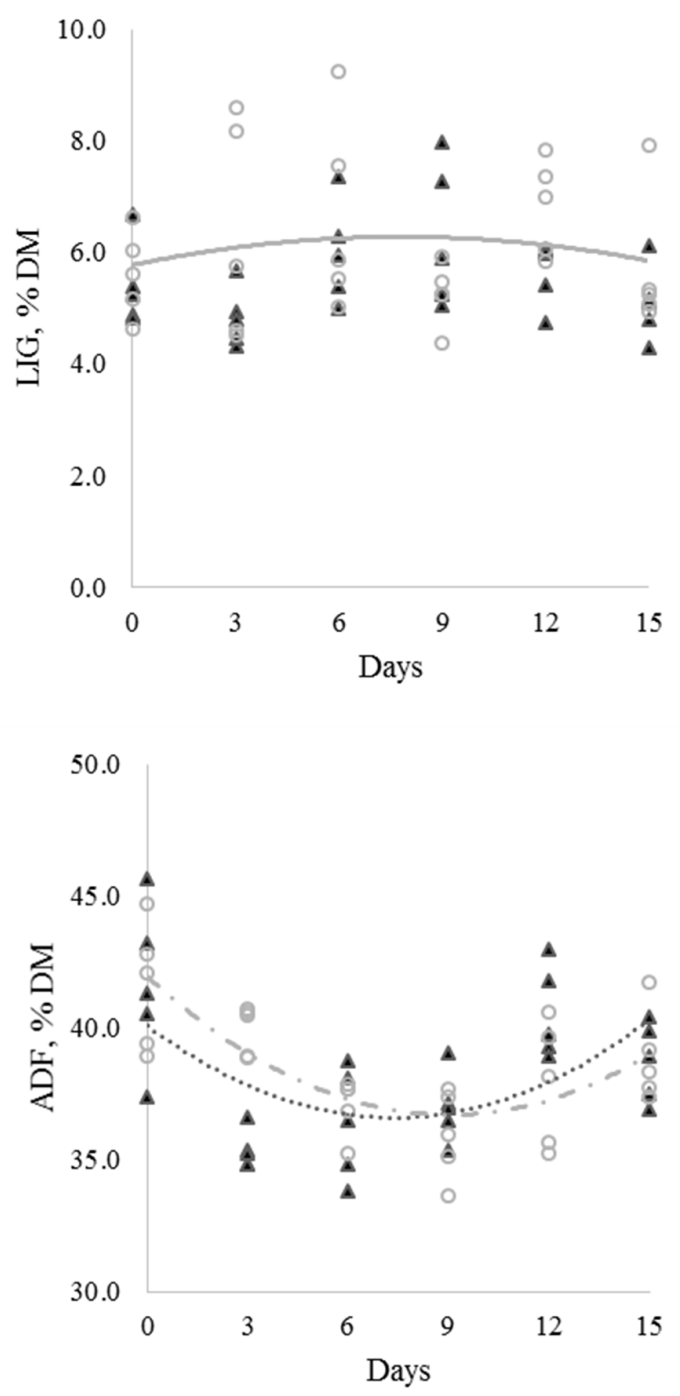

\section{Conclusions}

The chemical method provided greater recovery of dry phytomass and, despite resulting in a poor bromatological composition because of an insufficient plant dehydration, its use can still be

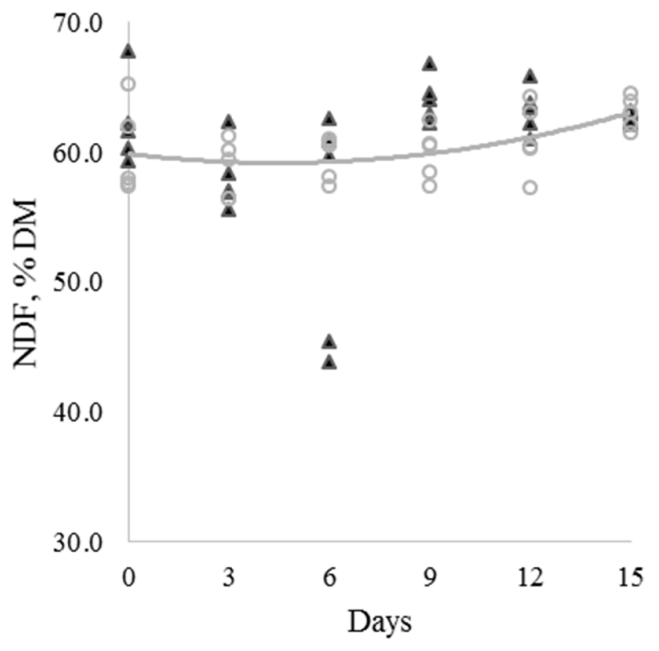

NDF: $60.2869-0.4279+0.0435 \mathrm{D}^{2}$

(CV: 6.3\%; R2: 0.146; $\mathrm{p}=0.0112)$

ADFm: 40.4238-0.9588D+0.0630D ${ }^{2}$

(CV: $\left.6.9 \% ; \mathrm{R}^{2}: 0.193 ; \mathrm{p}=0.05\right)$

ADFc: 43.1192-1.4453D+0.0787D 2

LIG: $5.8 \%$

$\left(\mathrm{CV}: 4.5 \% ; \mathrm{R}^{2}: 0.540 ; \mathrm{p}=0.0001\right)$

$\left(C V: 19.5 \% ; R^{2}: 0.055 ; p=0.1991\right)$

........ Mechanical - - Chemical —-Average

feasible in several cases by reducing the losses of dry matter due to climatic interferences.

However, further studies are still needed to indicate the proper use of glyphosate as a pre-drying method for black oats prior to ensiling. 


\section{Acknowledgments}

The authors want to thank the CAPES (Coordination for Improvement of Higher Education Personnel) for the scholarship granted in 2014 and in 2015, which made possible the accomplishment of this research.

\section{References}

AMARANTE JÚNIOR, O. P.; SANTOS, T. C. R.; BRITO, N. M.; RIBEIRO, M. L. Glifosato: propriedades, toxicidade, usos e legislação. Química Nova, São Paulo, v. 25 , n. 4 , p. $589-593,2002$.

ASSOCIATION OF OFFICIAL ANALYTICAL CHEMISTS INTERNATIONAL - AOAC. Official Methods of Analysis. 16 $6^{\text {th }}$ ed. Washignton DC: Ed. Arlington, 1995. v. 2, 474 p.

BERTO, J.; MÜHLBACH, P. Silagem de aveia preta no estádio vegetativo, submetida à ação de inoculantes e ao efeito do emurchecimento. Revista Brasileira de Zootecnia, Brasília, v. 26, n. 4, p. 651-658, 1997.

BOIN, C.; FLOSS, E. L.; CARVALHO, M. P.; PALHANO, A. L.; SOARES FILHO, C. V.; PREMAZZI, L. M. Composição e digestibilidade de silagens de aveia branca produzidas em quatro estádios de maturação. Boletim Indústria Animal, Nova Odessa, v. 62, n. 1, p. 35-43, 2005.

BUENO, A. V. I. Produção de silagem pré-secada de aveia (Avena spp.) emurchecida com uso de dessecante químico. 2015. Dissertação (Mestrado em Zootecnia) Universidade estadual de Maringá, Maringá.

CARVALHO, I. Q.; STRACK, M. Aveias forrageiras e de cobertura. In: LÂNGARO, N. C.; CARVALHO, I. Q. Indicações técnicas para a cultura da aveia. Passo Fundo: Ed. Universidade de Passo Fundo, 2014. cap. 1, p. 13-23.

COAN, R. M.; FREITAS, D.; REIS, R. A.; RODRIGUES, L. R. A. Composição bromatológica das silagens de forrageiras de inverno submetidas ou não ao emurchecimento e ao uso de aditivos. Ars Veterinária, Jaboticabal, v. 17, n. 1, p.58-63, 2001.

DAVID, D. B.; NÖRNBERG, J. L.; AZEVEDO, E. B.; BRÜNING, G.; KESSLER, J. D.; SKONIESKI, F. R. Nutritional value of black and white oat cultivars ensiled in two phenological stages. Revista Brasileira de Zootecnia, Brasília, v. 39, n. 7, p. 1409-1417, 2010.

FEROLLA, F. S.; VÁSQUEZ, H. M.; SILVA, J. F. C. D.; VIANA, A. P.; DOMINGUES, F. N.; AGUIAR, R. D.
S. Produção de matéria seca, composição da massa de forragem e relação lâmina foliar/caule+ bainha de aveia preta e triticale nos sistemas de corte e de pastejo. Revista Brasileira de Zootecnia, Brasília, v. 36, n. 5, p. 15121517, 2007.

FERREIRA, A. C. H.; RODRIGUEZ, N. M.; NEIVA, J. N. M.; CAMPOS, W. E.; BORGES, I. Características químico-bromatológicas e fermentativas do capimelefante ensilado com níveis crescentes de subproduto da agroindústria do abacaxi. Ceres, Viçosa, MG, v. 312, n. 54, p. 99-107, 2007.

FLOSS, E. L.; PALHANO, A. L.; SOARES FILHO, C. V.; PREMAZZI, L. M. Crescimento, produtividade, caracterização e composição química da aveia branca. Acta Scientiarum Animal Science, Maringá, v. 29, n. 1, p. 1-7, 2007.

GEBREHANNA, M. M.; GORDON, R. J.; MADANI, A.; VANDERZAAG, A. C. Silage effluent management: a review. Journal of Environmental Management, London, v. 143, n. 3, p. 113-122, 2014.

GOERING, H. K.; VAN SOEST, P. J. Forage fiber analysis (Apparatus, reagents, procedures and some applications). Washington: USDA, 1970. 379 p. (Agricultural Handbook, 379).

INSTITUTO AGRONÔMICO DO PARANÁ - IAPAR. Cartas climáticas do Paraná. Versão 1.0. Londrina: Ed. IAPAR, 2000. CD-ROM.

JACOBS, J. L.; HILL, J.; JENKIN, T. Effect of stage of growth and silage additives on whole crop cereal silage nutritive and fermentation characteristics. Animal Production Science, Clayton South, v. 49, n. 7, p. 595607, 2009.

JOBIM, C. C.; NUSSIO, L. G.; REIS, R. A.; SCHIMIDT, P. Avanços metodológicos na avaliação da qualidade da forragem conservada. Revista Brasileira de Zootecnia, Brasília, v. 36, p. 101-119, 2007. Suplemento Especial.

KRÜGER, M.; SCHLEDORN, P.; SCHRÖDL，W.; HOPPE, H. W.; LUTZ, W.; SHEHATA, A. A. Detection of glyphosate residues in animals and humans. Journal of Environmental \&Analitical Toxicology. v. 4, n. 2, p. 1-5, 2014.

MCDONALD, P. The biochemistry of silage. Edinburg: John Wiley and Sons Ltda, 1981. 226 p.

MEINERZ, G. R.; OLIVO, C. J.; VIÉGAS, J.; NÖRNBERG, J. L.; AGNOLIN, C. A.; SCHEIBLER, R. B.; HORST, T.; FONTANELI, R. S. Silagem de cereais de inverno submetidos ao manejo de duplo propósito. Revista Brasileira de Zootecnia, Brasília, v. 40, n. 10, p. 2097-2104, 2011. 
MESCHEDE, D. K.; VELINI, E. D.; CARBONARI, C. A.; TRINDADE, M. L. B.; GOMES, G. L. G. C. Efeitos do glyphosate nos teores de lignina, celulose e fibra em Brachiaria decumbens. Revista Brasileira de Herbicidas, Londrina, v. 10, n. 1, p. 57-63, 2011.

NISHINO, N.; LI, Y.; WANG, C.; PARVIN, S. Effects of wiliting and molasses addition on fermentation and bacterial community in guinea grass silage. Letters in applied microbiology, Maulen, v. 54, n. 11, p. 175-181, 2011.

ORCARAY, L.; ZULET, A.; ZABALZA, A.; ROYUELA, M. Impairment of carbon metabolism induced by the herbicide glyphosate. Journal of plant physiology, Lisboa, v. 169, n. 1, p. 27-33, 2012.

PARIS, W.; ZAMARCHI, G.; PAVINATO, P. S.; MARTIN, T. N. Qualidade da silagem de aveia preta sob efeito de estádios fenológicos, tamanhos de partícula e pré-murchamento. Revista Brasileira Saúde e Produção Animal, Salvador, v. 16, n. 3, p. 486-498, 2015.

PEREIRA, J. R. A.; REIS, R. A. Produção de silagem, pré-secada com forrageiras temperadas e tropicais. In: SIMPÓSIO SOBRE PRODUÇÃO E UTILIZAÇÃO DE FORRAGENS CONSERVADAS, 2001, Maringá. Anais... Maringá: UEM/CCA/DZO, 2001. p. 64-86.

POTT, C. A.; MÜLlER, M. M. L.; BERTELLI, P. B. Adubação verde como alternativa agroecológica para recuperação da fertilidade do solo. Revista Ambiência, Guarapuava, v. 3, n. 2, p. 51-63, 2007.

ROSÁRIO, J. G.; NEUMANN, M.; UENO, R. K.; MARCONDES, M. M.; MENDES, M. C. Produção e utilização de silagem de trigo. Revista Brasileira de Tecnologia Aplicada nas Ciências Agrárias, Guarapuava, v. 5, n. 1, p. 207-218, 2012.

STATISTICAL ANALYSIS SYSTEM INSTITUTE SAS Institute. SAS/STAT user's guide: statistics. $4^{\text {th }}$ ed. Version 6. Cary: SAS Institute Inc., 1993. v. 2, 943 p.
SILVA, D. J.; QUEIROZ, A. C. Análise de alimentos: métodos químicos e biológicos. 3. ed. Viçosa, MG: Universidade Federal de Viçosa, 2009. 235 p.

SILVA, R. A.; MATSUMOTO, S. N.; OLIVEIRA, L. S.; BRITO, C. L. L.; COSTA, A. A. Interferência de subdoses de glyphosate nas trocas gasosas em picãopreto e trapoeraba. Global Science and Technology, Rio Verde, v. 8, n. 1, p. 31-39, 2015.

TAIZ, L.; ZEIGER, E. Fisiologia vegetal. 3. ed. Porto Alegre: Ed. Artmed, 2004. 722 p.

TEDESCO, M. J.; GIANELLO, C.; ANGHINONI, I.; BISSANI, C. A.; CAMARGO, F. A. O.; WIETHOLTER, S. Manual de adubação e de calagem para os Estados do Rio Grande do Sul e de Santa Catarina / Sociedade Brasileira de Ciência do Solo. Comissão de Química e Fertilidade do Solo. 10. ed. Porto Alegre: Sociedade Brasileira de Ciência do Solo, Núcleo Regional Sul, 2004. $400 \mathrm{p}$.

VAN SOEST, P. J.; ROBERTTSON, J. B.; LEWIS, B. A. Methods for dietary fiber, neutral detergent fiber, and nonstarch polysaccharides in relation to animal nutrition. Journal of Dairy Science, Champaign, v. 74, n. 10, p. 3583-3597, 1991.

YANNICCARI M.; TAMBUSSI, E.; ISTILART, C.; CASTRO, A. M. Glyphosate effects on gas exchange and chlorophyll fluorescence responses of two Lolium perenne L. biotypes with differential herbicide sensitivity. Plant Physiology and Biochemistry, Paris, v. 57, n. 7, p. 210-217, 2012.

ZAMARCHI, G.; PAVINATO, P. S.; MENEZES, L. F. G.; MARTIN, T. N. Silagem de aveia branca em função da adubação nitrogenada e pré-murchamento. Semina: Ciências Agrárias, Londrina, v. 35, n. 4, p. 2185-2196, 2014.

ZOBIOLE, L. H. S. Water use efficiency and photosynthesis of glyphosate-resistant soybean as affected by glyphosate. Pesticide Biochemistry and Physiology, San Diego, v. 97, n. 3, p. 182-193, 2010. 
